\title{
TEXT AS A WAY OF PROFESSIONALLY ORIENTED SPEECH COMPETENCE OF HUMANITIES AND PEDAGOGICAL COLLEGE STUDENTS
}

\author{
Skrypnyk N. I., Homiak I. M.
}

\section{INTRODUCTION}

New priorities for educational competency are set out in the National Doctrine of Development of Ukrainian Education, the Law of Ukraine "About Education", the National Program "Education" (Ukraine of the 21 st Century), the Decree of the President of Ukraine "About the National Strategy of Educational Development in Ukraine until 2021". Today, the modern world requires individuals who are ready to communicate effectively and think critically, professionals who are able to work in a team, set a goal and achieve it, communicate in professional broadcasting in all spheres of a democratic society. The communicative and vocational competence is particularly important in higher education institutions, which is dictated by the demands of time and is defined as one of the key competences of the modern educational process.

Scientists such as M. Bakhtin ${ }^{1}$, I. Halperin ${ }^{2}$, L. Loseva ${ }^{3}$, O. Moskalskaya ${ }^{4}$ and others, emphasize that the text itself is the basis that integrates elements of language, where all linguistic units acquire natural functions and, accordingly, the text is one of the effective types of cognitive activity for the development of communication and speech competence.

The main unit of speech activity is the text. Each text, covering a specific topic, contains specific information and is aimed at performing a specific communicational task. The importance of studying language in the course of speech activity, taking into account the processes that occur during listening and when talking about the different roles of the speaker and listener in the communication process, was drawn by a large number of scholars who represented the psychological paradigm. Yes, the idea of different

${ }^{1}$ Бахтин М.М. Проблемы речевых жанров. Литературно-критические статьи. Москва : «Художественная литература», 1986. С. 428-472.

${ }^{2}$ Гальперин И.Р. Текст как объект лингвистического исследования. Москва : Едиториал УРСС, 2004. 144 с.

3 Лосева Л.М. Как строится текст: пособие для учителей. Москва : Просвещение, 1980. $96 \mathrm{c}$.

${ }^{4}$ Москальская О.И. Грамматика текста. Москва : Высшая школа, 1981. 183 с. 
understanding of words and expressions by the speaker and the listener in the communication process is found in Potebna, Steintal, Baudouin de Courtenay.

However, the attempt to study the language with communication participants has led to the creation of such a complex object of study that the ways that existed at this stage of development of the conceptual apparatus linguistics could not be adequately described. In this regard, introducing into the field of linguistics a new object of study - systemic relations in language - representatives of the system-structural paradigm, passing to the description of the higher levels of the linguistic system, created a base for the study of a new object - text, in its statics and dynamics ${ }^{5}$.

The interest of scholars in the problems of the text is evidenced by the large number of works of Ukrainian and foreign researchers, in particular N. Harutyunova, F. Batsevich I. Bechta, I. Halperin, S. Karaman, V. Karasyk, G. Kolshansky, M. Kochergan, M. Makarov, L. Friedman, Y. Habermas, Z. Schmidt and others. Definitions of the term "text" refer to one of the controversial issues that are being discussed ambiguously, by linguists (D. Barannik, A. Koval, O. Ponomaryov, O. Selivanov, etc.), psychologists (L. Vygotsky, I. Zimnya, T. Ladyzhenskaya, O. Luria, I. Sinitsa, etc.) and lingvodidakts (O. Bilyaev, O. Goroshkina, V. Melnichiko, M. Stelmakhovich, I. Khomyak, etc.).

The object of the study is to develop the communicative and vocational competence of future vocabulary teachers in the process of working with the text. The purpose of the article is to investigate the originality of the text and to determine its role in the process of communicative speech act. According to this goal, the following tasks were defined: to clarify the definitions of the key concepts "text", "educational text" "oral text", "written text", "communicative and speech competence of students-philologists", to study the functioning of text in communication, to determine the need for text in the process of speech activity and related problems, differentiate texts by form of communication, analyze types and genres of speech.

The realization of the stated purpose and the solution of the set tasks were carried out through the use of the following methods of research: analysis, synthesis, generalization of scientific researches on the problem of formation of communicative-speaking competence of students in the process of working with the text.

Thus, the text is a complex communicative unit of the highest order, which is a prototype, product, and object of communicative-cognitive

5 Цвиллинг М.Я. Общественно-политический и научный текст как предмет обучения иностранным языкам. Москва : Наука, 1987. С. 150. 
activity, and is also an effective didactic means of improving the communicative-speaking competence of future philological teachers.

\section{Text as a component of the formation of communicative-speaking competence of students-philologists}

Text is an exercise of linguistic competence in the process of communicative-speaking activity. For researchers, the distinction is made between the concepts of "text", "speech", "discourse", which are extremely important for understanding the term "text". In the early 70's of XX century. an attempt was made to differentiate the concepts of "text" and "discourse" by including the category of situation. Discourse was interpreted as "text plus situation" and text accordingly - as "discourse minus situation". The text is a phenomenon narrower than discourse and has features of a closed system, as well as a written and oral form of embodiment.

Note that broadcasting arises because of the need for communication. It is always aimed at the listener and intended to communicate with him. Basic in the speech development of language learners is the improvement of the ability to use speech as a means of communication. I. Shevchenko and O. Morozova under the speech understand speech activity, which takes place in a broad socio-cultural context, is a set of process and result, characterized by continuity and dialogism ${ }^{6}$.

According to $\mathrm{T}$. Ladyzhenskaya, the set of conditions that determine broadcasting, constitute a communication situation ${ }^{7}$. The speech situation is an important component in the communication process, as it not only stimulates expression, but also plans its form, style, type and genre, creates certain conditions for communication.

Speech competence is a basic indicator of the professional competence of the modern specialist in philological profile, and therefore can not be applied only to a particular academic discipline, and should cover the entire range of proposed subjects, which is provided for by the appropriate educational and professional training program for future teachers. According to L. Mamchur, "An important factor in the formation of the speech competence of a future teacher-philologist is his speech development, which involves mastering the system of speech knowledge and skills required for communication in different types of speech activity. An indicator of this development is communicative competence, that is, the ability to communicate, which leads to the active use of language, the ability to perceive and reproduce the

${ }^{6}$ Дискурс як когнітивно-комунікативний феномен : монографія / під заг. ред. I.C. Шевченко. Харків : Константа, 2005. 356 с.

7 Ладыженская Т.А. Живое слово: устная речь как средство и предмет обучения : учеб. пособие. Москва : Просвещение, 1986. С. 89. 
content of another's language, to produce their own, demonstrating their intellectual development, cultural achievements and values" $"$.

The perception of text is a much more complex process than the perception of a communicative act: the content of the whole text is modulated by the interpretation of certain communicative acts. The perception of the text includes the reception of elements of language that the person hears or sees, establishing their relationship and forming an idea of their meaning".

In the "Linguistic Encyclopedic Dictionary" the following interpretation of the definition is proposed: "Text (from Latin textus - fabric, plexus, connection) - a sequence of semantic units united by a semantic connection, whose main properties are coherence and purpose ${ }^{10}$.

According to I. Halperin, the text is «a work of speech-creative process, characterized by completeness, objectified in the form of a written document, literarily processed, consisting of a name (title) and a number of special units (transphrasal unities), combined different types of lexical, grammatical, logical, stylistic communication, which has a definite purpose and pragmatic attitude"11.

The basis of our exploration is the definition found in the studies of I. Kovalik, L. Matsko, M. Ivy, who define the text as "a written or oral flow, which is a sequence of sound, graphemic elements in syntactic structures (sentences), which express a complex of related judgments"12; A. Selivanov is of the same opinion, understanding the text as a verbal mediator of communication, for which he is a "holistic sign form of broadcasting organization"13.

It is now a clear fact that increased attention to the text, its comprehension and production occurs in the communication process. In our opinion, the text should be regarded as both the basic unit of speech, and as an expression, and as a product of speech, as well as as a completed speech

8 Мамчур Л. Формування мовно-риторичної компетентності майбутнього вчителя-словесника. Проблеми підготовки сучасного вчителя : збірник наук. праць Уманського державного педагогічного університету імені Павла Тичини. Умань : ФОП Жовтий О.О. 2013. Вип. № 8 (Ч. 2). С. 182-186.

${ }^{9}$ Белянин В.П. Писхолингвистика : учебник. Москва : Московский психологосоциальный институт, 2003. С. 103.

${ }^{10}$ Лингвистический энциклопедический словарь / гл. ред. В.Н. Ярцева. Москва : Сов. Энциклопедия, 1990. 685 с.

${ }^{11}$ Гальперин И.Р. Текст как объект лингвистического исследования. Москва : Едиториал УРСС, 2004. С. 45.

\footnotetext{
${ }^{12}$ Ковалик I.I. Методика лінгвістичного аналізу тексту. Київ : Вища школа, 1984. C. 7.

13 Селиванова Е.А. Основы лингвистической теории текста и коммуникации : учеб. пособие. Киев : Фитосоциоцентр, 2004. С. 7.
} 
work, which is characterized by informativeness, integrity, thematic unity, has its own structure, means of "coherent" parts.

You can take into account that you use the up-to-date content and navigation when using this time, as well as being the source of all my units, categories, and browse the working vocabulary. For example, G. Sommer, under the term "educational text", creates a text that exists for medium purposes. At the time when it was lost that killing the main criterion was to play a didactic criterion, not a linguistic one. The main didactic criterion of the educational text G. Sommer sees in its function, which is used in the generation of new oral or written texts ${ }^{14}$.

An important tool for developing language skills in the educational process, as well as a source for learning language units, is a textbook. For example, G. Sommer claims it an «educational text» as used for educational purposes. The scientist points out that the didactic criterion should play the main criterion, not the linguistic one. The main didactic criterion of the educational text G. Sommer considers its function, which is manifested in the generation of new oral or written texts ${ }^{15}$.

Thus, T. Kudryavtseva proposes to consider educational texts as an object of learning and as a means of learning. The scientist states: "Types of educational text as an object of learning are differentiated from the content side by means of construction; and types of educational text as a means of learning differing in formal characteristics"16. N. Goncharova divides the educational texts into descriptions and stories, reflections and proofs, arguing that "since any content is expressed in a particular expression, the text, the logical structure of each particular text will be determined by the logical structure of the type of content"17.

Summarizing everything, we can conclude that the educational text as a means of forming communicative, linguistic, speech and socio-cultural competence is endowed with rich didactic potential. In context of the globalization process, which has covered all aspects of social life and the sphere of education, the educational text should be focused on solving a specific didactic task in different situations of the educational process, on the formation of key and subject competences in students.

${ }^{14}$ Sommer G. Types of written educational texts for the development of speaking and writing. Issues of linguistics and linguistics. MAPRYAL Conference Proceedings (23-24 Apr 1996, Krakow). Krakow : Wydawnictwo Naukowe WSP, 1996. P. 223-228.

${ }^{15}$ Ibid.

16 Кудрявцева Т.С. Функционирование текста в учебном процессе. Москва : Наука, 1984. С. 40.

${ }_{17}$ Гончаренко С.У. Український педагогічний словник. Київ : Либідь, 1997. C. 230 . 
At the heart of the formation of communicative-speaking competence of future Ukrainian language teachers, the key is undoubtedly the oral and written text. In the linguistic education the text is referred to as "a segment of speech or expression (oral and written) relating to a specific field. In the process of performing a certain task, it becomes an act of speech activity and can be both a support and a goal, both a product and a process" $" 18$. According to M. Vashulenko, I. Hudzik, T. Donchenko, I. Zimnya, V. Melnichiko, M. Pentylyuk, I. Khomyak, O. Khoroshkovskaya, the text is a universal product for the development of productive and receptive types of speech activity.

In the process of listening, it becomes important to be able to perceive utterances (phonetic skills), to identify the language of the message (linguistic skills), to understand the messages (semantic skills), to interpret the messages (cognitive skills). When reading, it is first and foremost about the ability to perceive written text (technical reading skills), to identify messages (language skills), to understand messages (semantic skills) ${ }^{19}$.

Oral text is text created verbally. Written text is created or recorded in writing. These types of texts are not only a means of language learning, but also an object of assessment. In particular, in the speech test, oral text is evaluated as a result of speech according to the following parameters: "discursive organization, interaction, pronunciation, grammar and vocabulary" 20 . Written text in the assessment of productive skills - writing is assessed by the criteria "content, communicative achievements, structure, language (vocabulary and grammar)"

We believe that text itself is an important means of assimilating new material and at the same time an indicator of learning outcomes based on texts authored by future philologists in accordance with educational and professional programs. It should also be remembered that the text is a coherent statement that consists of a group of sentences united by the theme and the main purpose, as well as the author's attitude to what is being communicated. There are three logical parts to the text: the beginning, the main part, and the ending.

Nina Stankevich interprets the text as the basis of any kind of speech activity: dialogue, audiotext, text for reading, written work. In her opinion, in the analysis of types of speech activity educational texts can be classified

18 Загальноєвропейські рекомендації з мовної освіти: вивчення, викладання, оцінювання / наук. ред. С.Ю. Ніколаєва. Київ : Ленвіт, 2003. С. 10.

${ }^{19}$ Там само. С. 273.

20 Handbook for teachers for exams from 2016. Cambridge English. URL: https://www.cambridgeenglish.org/Images/167791-cambridge-english-firsthandbook.pdf (дата звернення: 18.04.2020).

${ }^{21}$ Ibid. 
in various ways ${ }^{22}$. We propose to classify the types of educational texts by the following criteria: the content and method of presentation of the material - text-story (oral or written text: article, work, translation, letter, message), text-description (genres: landscape, portraiture, characteristics of people, phenomena), text-reasoning (reflection-statement, reflectionobservation, reflection with evidence); by the nature of psychological and emotional influence on the participants of the educational process - textillustration (drawing), text-scheme, text-symbol; by results of educational interaction - text-algorithm, text-instruction, text-test. In the process of working on these types of texts, students of philology are formed appropriate communication and speaking skills, skills, social experience, spiritual values.

It is the text as didactic material that represents coherent speech, interpersonal communication, promotes the acquisition of national and universal cultural and spiritual values, expression of speech, norms governing relations between people.

\section{Formation of future teachers-philologists skills in working with text}

The course of education recipients' speech development lies through the understanding of read or heard text and involves the activation of various types of speech activity. To the technological support of the formation future teachers-philologists' professionally oriented speech competence in the process of working with the text, we include forms, methods, techniques and teaching aids. The speech direction of the competence approach involves methods of forming, in fact, speech and communication competence.

The communicative method guides students to the creation of the text and involves the implementation of all stages of the speech activity in their logical sequence, starting with the orientation in the subject of the future work and ending with receiving feedback. The techniques of this method include: creating speech situations or selecting them from life, role-playing games, elements of interactive cooperation and various activities that encourage speech, and so on.

Effective forms of expression students-philologists' speech competence in the course of work with the text are considered frontal, group, paired and individual.

In the context of our study, where text is a means of improving speech competence, we consider such effective theoretical and practical methods and techniques as follows: observation of features and functioning of speech units, comparison of speech units, construction (conversion) of speech units,

\footnotetext{
${ }^{22}$ Станкевич Н. Види мовленнєвої діяльності в аспекті лінгводидактики. Теорія $i$ практика викладання украӥнської мови як іноземної : збірник наук. праць. Львів : Видавн. центр ЛНУ імені Івана Франка, 2007. Вип. 2. С. 43.
} 
production of speech units utterances, essays, drafting, compositional schemes, text translation expressive reading aloud, reading text silently, working with deformed text, composing text by keywords, composing by text, by topic, by method of creative work (oral and written works and translations), drafting business papers, projects, text editing, rhetorical text analysis, linguistic analysis of text, dialogue with the author or character of the text, drafting dialogues and monologues, linguistic commentary, reflection, thinkings on the philosophy of life, the method of associations (promotes the formation of national consciousness, enriches vocabulary, the ability to perceive subtext), speech training, etc.

We refer to the traditional methods of speech direction in the process of working with the text: the teacher's story (promotes the development participants' knowledge during the educational process, but does not ensure the development of facilities and skills, so its logical continuation is different types of exercises, tasks, training); conversation (introduction at different stages of a heuristic conversation, containing communicatively oriented problematic questions, creates favorable conditions for the formation of students' vocational speech competence), observation (speaking is one of the sources of learners' knowledge, which is the basis for learning needed to create your own related statements); work with the textbook (a special place in the experimental study is the work with the textbook (vocabulary, reference literature), as a method of teaching necessary for the development of students' activity, their organization in life and professional activity in general, and communicative and vocational competence in particular; to develop such productive speech activities as writing, which requires careful pre-planning and organization of all stages of writing works; reading texts posted in the textbook, in the supplementary literature, on the Internet, according to A. Crawford, W. Saul, and S. Mathews, it is "an activity that provides reading comprehension in the part of the lesson when the knowledge-building phase takes place, in the use of narrative artistic or informative text" ${ }^{\prime 3}$, that is, reading is a part of speech-language communication that provides the development of the ability to perceive information, to use it to express their own point of view in the process of speech communication); method of exercises (an effective way of forming specific facilities and skills of students-philologists, and in the area of our study is the speech competence of future teachers; the element of each exercise should be communicative-speaking tasks - verbal and non-verbal

23 Технології розвитку критичного мислення учнів / А. Кроуфорд, В. Саул, С. Метьюз, Д. Макінстер; Наук. ред., передм. О.І. Пометун. Київ : Видавництво «Плеяди», 2006. С. 46. 
actions that organize students' speech communication to professions, their involvement in professional communication).

We propose a sample. Read the text, get the title. Specify the ways by which the sentence is combined into the text. Any pores are attractive and beautiful bush viburnum. In the spring it is decorated with delicate green inflorescences. And the summertime is enchanted by the magnificent greenery of the thick paw leaves. In early autumn, viburnum is already decorated with rosy berries. Before the first frost the plant is proud of its golden dress. In winter, guelder rose attracts with well-frozen, already completely edible and sweet berries. Bright flames of light fade in the midst of the bare, dark twigs.

In the world of information technology, creative professionals with new ideas are valued. Rather fast, a student can become a "professional" in the area that interested him. The teacher should also support the participant of the educational process on the way to acquisition of subject competences. Nowadays, effective methods are the use of innovative methods, which increase the students' interest in learning linguistics training by developing intrinsic motivation and by moving the centre of the learning process from the teacher to the student. Thus, in the context of our research we can use the following: case method ("based on the concept of students' mental abilities development and aimed at developing creative thinking. This method contributes to the successful achievement of a number of educational and educational goals: the acquisition of previously unknown information, the ability to work with literature, improving ability to communicate" ${ }^{24}$. Thus, in the process of analysis, synthesis and discussion, students select the necessary information, supplement it and communicate, while developing their own professionally oriented speech competence). We present a sample of case method on current issues in the culture of speech, "How to apologize correctly", "How to express your request", "Polite request - polite refusal". "Concepts of Language Development of Ukraine", "Basic Information on Philological Scientists of the XX Century", "Ukrainian Language: History and Modernity", "Cabinet of the Ukrainian Language", "Professionals of the Philological Branch and Methods of their Creation", "The Phenomenon of Mythology of the Ukrainian Language" etc; speech training (during the training a communication surroundings is created, characterized by openness, interaction of participants, equality of their arguments, accumulation of shared experience, opportunity to receive frank information and express their own opinion. "This is a form of training that is aimed at developing speaking skills and effective behaviour in different

\footnotetext{
${ }^{24}$ Пентилюк М. Актуальні проблеми сучасної лінгводидактики : збірник статей. Київ : Ленвіт, 2012. С. 132.
} 
communication situations. Conducting such trainings in higher education institutions is the basis for forming the speech competence of future professionals ${ }^{\text {} 25}$.

It was effective to conduct a speech training "Communicate in Ukrainian" or "Culture of communication over the phone". Task. Listen to the text. Analyze how to make a phone call. Compare the culture of telephone communication with your own speaking over a mobile phone. Based on the text and your own generalized observations, formulate rules of communication on the mobile phone, identifying other positions that were not named in the text.

In our opinion, the following training technologies can be used in language studies: Formula of the profession. Students should formulate a formula for their future profession using the notation of all the qualities necessary for productive work, for example, $a$-attention, $o$ - organization, $m$ - mutual aid, $c$-communication, $w$-work, $k$ - knowledge. Such an exercise develops the skills of self-organization, logical thinking and the ability to set a goal and achieve $\mathrm{it}^{26}$.

One of the most important components of the educational process, according to leading methodologists, is the introduction and application of interactive methods (they will enrich the personal experience, value orientations and professionalism of students-philologists (presentation, heuristic conversations, role-playing games, discussions, brainstorming, "aquarium", "associative bush", competitions with practical tasks and their subsequent discussion, project, creative activities, use of multimedia computer programs, etc.).

For example, when using the method "Philological Workshop", students play the role of linguists, researchers. Tasks are extremely diverse: text study, linguostylistic or ideological and artistic analysis of the text; "The Museum of Mistakes". Students are museum workers. Some relics fall into them, but time has left its mark - obliterated parts of sentences, indistinctly spelled words, no punctuation marks and mixed places of words when glued together. The task is to reproduce the text, explain the mistakes, and correct them. And sometimes you need to edit a text-translation from an ancient language, made by not enough competent researchers; "The Art of Oratory". Students-writers. The task is to write a creative work, an article ... Only the topic of the work may be suggested, and may be support words or word combinations, depending on the proposed topic.

\footnotetext{
${ }^{25}$ Homiak I., Skrypnyk N. Training technologies as one of the forma of development of non-stardard communication in Ukrainian lessons. Norwegian Jornal of development of the Inernational Science. Oslo, Norway. 2019. № 37. C. 9.

${ }^{26}$ Ibid. C. 10.
} 
A real form of material expression of the project is a written work (a work on a moral, ethical or social topic). It is desirable that the project title be laconic and concise, for example: "I am Ukrainian", "Dignity", "Patriotism", "Responsibility for my own actions", "My dream institution", "My Ukraine is embroidered" and so on. This type of project should form the skills of linguistic analysis participants (actual sentence articulation, method of communication between sentences, general question to text, functional purpose, sphere of use, linguistic features, sentence structure, rhetorical figures, inversion, tropes, symbolism, ethics) ${ }^{27}$.

Linguistics does not clearly define the term learning tools, for example, the pedagogical dictionary defines that "learning tools are objects that cause sensomotor stimuli (affect vision, hearing, touch, etc.) and facilitate the participants in the educational process of cognition of reality. These can be real objects and their model, figurative, verbal or symbolic substitutes" 28 . In our research, text is an effective tool for improving students' professionally-oriented speech skills.

The analysis of pedagogical and methodological literature allows to identify the following types of ways, which are aimed at forming the speech competence of students-philologists in the process of working with the text: verbal 1) oral and written texts; 2) communicative speech exercises and tasks; 3) topics of monologues and dialogues; 2) visual (interactive whiteboard, tables, diagrams, illustrations, slides: specific content (text-illustrative and text-activity) and abstract content (verbal-graphic, graphic, picture)); 3) electronic means (computer, Internet, multimedia; theoretical material can be presented electronically in the form of presentations, slideshows. For example, write a narrative text of art style on the theme "Flowers are the eyes of nature" and to present it in the form of a slide-show); 4) paralinguistic means (in the process of forming students' professional speech competence the inclusion of these means is necessary, because the knowledge, understanding and appropriate the use of facial expressions, gestures, posture, distance between participants in the educational process helps to avoid misunderstandings in communication and speech interaction).

Samples of verbal tasks. Make a coherent statement, taking the thesis submitted: "Bread is honoured in every family because...", "A Ukrainian does not imagine his life without a song because...".

${ }^{27}$ Скрипник Н.І. Застосування проєктної технології у процесі вивчення сучасної української мови у закладах вищої освіти. Педагогічний часопис Волині: науковий журнал. Луцьк : СНУ імені Лесі Українки, 2019. № 4(15). С. 75.

${ }_{28}$ Гончаренко С.У. Український педагогічний словник. Київ : Либідь, 1997. C. 124. 
Task. Prepare a post on the topic: "Formation of the ideas of the text educators" using the recommended literature.

Task. To form students' editing skills, a team teacher selects appropriate text for team analysis, which needs to be analyzed and edited. When studying which topic in the text section should you use similar tasks?

Task. Each text has its own characteristics: informative, headline presence, cohesiveness, semantic integrity, structural, completeness. Consider the content of the following features in a specific text example.

Task. Read the text. Select a title. Identify the micro-themes, make a plan. The Ukrainian rushnyk has passed through the ages and now symbolizes the purity of feelings, the depth of love for their children, for all who do not call their hearts. The rushnyks, which were often hung over windows and doors, were supposed to protect the house from all filth. Therefore, both the ornament and the patterns played the role of amulets. A dotted diamond in the middle meant a planted field, a flowerpot or flower - a tree of life. The red and black threads in the embroidery of the mother towel are our eternal love and sorrow. That is our original fate.

Sample of visual exercise. Make the text according to the scheme.

\begin{tabular}{|c|c|c|}
\hline \multicolumn{3}{|c|}{ Topic. The greatest wealth is the legends of his native land } \\
\hline $\begin{array}{l}\text { I micro theme } \\
\text { The greatest wealth }\end{array}$ & $\begin{array}{l}\text { II micro theme } \\
\text { Knowledge of legends }\end{array}$ & $\begin{array}{c}\text { III micro theme } \\
\text { Patriotism } \\
\text { is not to buy }\end{array}$ \\
\hline $\begin{array}{l}\text { The first thematic } \\
\text { sentence } \\
\text { I believe that every } \\
\text { real Ukrainian } \\
\text { deserves wealth, and } \\
\text { the greatest wealth is } \\
\text { legends }\end{array}$ & $\begin{array}{c}\text { The second thematic } \\
\text { sentence } \\
\text { To be a true patriot } \\
\text { you need to read, } \\
\text { protect, know the } \\
\text { legends of your native } \\
\text { land }\end{array}$ & $\begin{array}{l}\text { The third thematic } \\
\text { sentence } \\
\text { Here is the patriotism } \\
\text { for the money } \\
\text { not to buy }\end{array}$ \\
\hline $\begin{array}{c}\text { Themed word } \\
\text { легенди }\end{array}$ & $\begin{array}{c}\text { Themed word } \\
\text { знати легенди }\end{array}$ & $\begin{array}{c}\text { Themed word } \\
\text { за гроші }\end{array}$ \\
\hline
\end{tabular}

An important factor in the formation of speech competence is the common students' educational activity, which is carried out in the process of their communication. It can be organized at the expense of a specific system of questions aimed at determining the level of awareness of information givers. These questions are offered to students at different stages of the text work: after initial perception, re-reading to establish the sequence of events, analysis of factual and figurative content. At these stages we also work on the accumulation of active vocabulary of participants in the educational process, the formation of accentuation norms of the Ukrainian literary language. 
Another stage of learning text information is the formation of skills for its interpretation, paraphrase. By dividing the text into logically complete parts, students compile a storytelling algorithm using imaginary drawing, sequential "film frames". And the teacher writes it in the form of sentence structures on the board. According to the plan, an oral retelling is built.

In terms of form, texts are traditionally divided into dialogue (dialogical text), monologue (monologue text), polylogue. The implementation of the practical-activity component of the research can be reproduced through the creative production of texts of different types, genres, styles. Compared to dialogue, monologue cohesive messages are a complex type of speaking activity that students perform on their own, or with reliance on basic phrases, sentences, and more.

Studying the topic "Technology of designing lessons in the development of connected speech" of discipline "Methods of teaching Ukrainian", which has an applied character and plays a leading role in the professional training of future teachers-philologists, students create verbally (or in writing) detailed, concise, selective, creative translations and works-stories, worksdescriptions, works-thinks on congenial and clear topics. The main task of the lessons of the development of coherent speech is the formation of the necessary text-writing skills for students on the basis of mastering their textual knowledge.

Task. Plan independently a system of work aimed at forming the concept of "text-story", get the necessary didactic material, using professional periodical sources.

Task. Among the types of texts, the most complex is text-consideration. Explain the reasons for difficulties in constructing consideration, find ways to improve the ability to build considerations.

Task. Choose the text-story, text-description, consideration. Explain on what grounds they can be distinguished.

Task. For each of the types of texts, the supporting parts are specific parts of the language: verbs for narratives, adjectives for descriptions. For example, read the descriptions and identify their style and vocabulary. What is the role of lexical means in each of them?

Task. Prepare information on "Forming intonation skills as you study the "Text section". Justify the role of familiarizing the participants of the educational process with the texts of different types in forming the expressiveness of speech.

In accordance with the educational and professional program "Ukrainian Language and Literature" students learn to compose in the class different texts: poems, fairy tales, stories, texts of official and business nature: 
greetings, invitations, announcements, $\mathrm{CV}$, resume, etc.; nonfiction texts: essays, notes, interviews, etc.

In the process of drafting business papers, special attention should be paid to the purpose and structure of the document, especially the language arrangement. The documents are made according to the model, which is obligatory for all business papers. A statement or essay is also written according to the appropriate scheme. Properly drawn up are only those documents or written works that clearly and consistently provide accurate information with compliance with the relevant details, design rules and, of course, the rules of Ukrainian spelling.

Text in students-philologists' system of speech competence is the object and means of receptive speech activity, in the process of which the student is a listener and reader, and at the same time the text is both a product and the result of productive speech activity.

Equally difficult and responsible is the improvement of written language, that is, the process of text creation. It is necessary during the preparatory work to consider the topic of expression in accordance with the stated purpose, to determine the main idea of the message, to make a plan of the work, taking into account the type and structure of the text, to select vocabulary, expressive means of speech according to the style of speech.

\section{CONCLUSIONS}

As a result, it can be stated that the comprehension of the text is a complex process; it is built according to logical rules. Text material should be informative and appropriately selected, to meet the needs of today. The greatest element in the structure of the text is the complete speech communication, the conversation that correlates in speech with the macro or micro text. Oral and written texts function through speech events.

On the basis of the analysis of scientific works, the characteristics of oral text, written text, educational text, types of educational text are given. Attention is drawn to the fact that the educational text of any textbook, manual must meet the following requirements: logic, coherence, integrity, accessibility, science, consistency, continuity, integrative knowledge. It is found that the precision, logic, coherence, expressiveness that are achieved through evidence, reasoning is an important quality of educational text. When learning linguistic topics, textbooks should be used as it encourages students to build coherent statements.

But also such means will be the main means of formation in the applicants of the ability to build expression in oral and written forms of speech. 
It is determined that if we consider speech as a speech product, then not only retellings and works, but also the following means: messages, instructions, feedback on a work of art, scientific-popular article, oral answer to class, report on work performed, speech at the meeting of the circle, welcome speech, letter, diary of life and observations, written answer to class, abstracts, abstract of the article, reflection (reasoning) on this or that theme, will be the main means of formation applicants' ability to build expression in oral and written forms of speech.

Consequently, text can be presented as a subject of study (what should be taught), as a means of learning (in what way to teach), as a product of teaching - texts created independently by students-philologists, and text is the result of learning.

\section{SUMMARY}

The formation of professionally oriented speech competence is an integral part of the modern educational process. Each specialist's training is of particular relevance in the new economic, linguistic and pedagogical context, since communication provides career opportunities and professional speaking success. It is determined that the text should now be considered as a universal teaching tool that provides a comprehensive knowledge of the language, normative use of language signs and on this basis contributes to the improvement and expression of the communicative and speaking facilities and skills of future teachers of Ukrainian language.

\section{REFERENCES}

1. Бахтин М.M. Проблемы речевых жанров. Литературнокритические статьи. Москва : «Художественная литература», 1986. C. $428-472$.

2. Белянин В.П. Писхолингвистика : учебник. Москва : Московский психолого-социальный институт, 2003. 232 с.

3. Гальперин И.Р. Текст как объект лингвистического исследования. Москва : Едиториал УРСС, 2004. 144 с.

4. Гончаренко С.У. Український педагогічний словник. Київ : Либідь, 1997. 376 с.

5. Гончарова Н.Н. Структурные особенности учебных текстов дисциплин лингвистического цикла. Система $i$ структура східнослов'янських мов : міжкафедральний збірник наук. праць. Київ : Національний педагогічний університет імені М.П. Драгоманова, 1998. С. 229-237.

6. Дискурс як когнітивно-комунікативний феномен : монографія / під заг. ред. І.С. Шевченко. Харків : Константа, 2005. 356 с. 
7. Загальноєвропейські рекомендації з мовної освіти: вивчення, викладання, оцінювання / наук. ред. С.Ю. Ніколаєва. Київ : Ленвіт, 2003. $273 \mathrm{c}$.

8. Sommer G. Types of written educational texts for the development of speaking and writing. Issues of linguistics and linguistics. MAPRYAL Conference Proceedings (23-24 Apr 1996, Krakow). Krakow : Wydawnictwo Naukowe WSP, 1996. P. 223-228.

9. Ковалик I.I. Методика лінгвістичного аналізу тексту. Київ : Вища школа, 1984. 119 с.

10. Кудрявцева Т.С. Функционирование текста в учебном процессе. Москва : Наука, 1984. 184 с.

11. Ладыженская Т.А. Живое слово: устная речь как средство и предмет обучения : учеб. пособие. Москва : Просвещение, 1986. 127 с.

12. Лосева Л.М. Как строится текст: пособие для учителей. Москва : Просвещение, 1980.96 с.

13. Лингвистический энциклопедический словарь / гл. ред. В.Н. Ярцева. Москва : Сов. Энциклопедия,1990. 685 с.

14. Мамчур Л. Формування мовно-риторичної компетентності майбутнього вчителя-словесника. Проблеми підготовки сучасного вчителя : збірник наук. праць Уманського державного педагогічного університету імені Павла Тичини. Умань : ФОП Жовтий О.О. 2013. Вип. № 8 (Ч. 2). С. 182-186.

15. Москальская О.И. Грамматика текста. Москва : Высшая школа, $1981.183 \mathrm{c}$.

16. Пентилюк М. Актуальні проблеми сучасної лінгводидактики : збірник статей. Київ : Ленвіт, 2012. 256 с.

17. Селиванова Е.А. Основы лингвистической теории текста и коммуникации : учеб. пособие. Киев : Фитосоциоцентр, 2004. 336 с.

18. Скрипник Н.I. Застосування проєктної технології у процесі вивчення сучасної української мови у закладах вищої освіти. Педагогічний часопис Волині: науковий журнал. Луцьк : СНУ імені Лесі Українки, 2019. № 4(15). С. 72-78.

19. Станкевич Н. Види мовленнєвої діяльності в аспекті лінгводидактики. Теорія і практика викладання украӥнської мови як іноземної : збірник наук. праць. Львів : Видавн. центр ЛНУ імені Івана Франка, 2007. Вип. 2. С. 40-47.

20. Технології розвитку критичного мислення учнів / А. Кроуфорд, В. Саул, С. Метьюз, Д. Макінстер; Наук. ред., передм. О. І. Пометун. Київ : Видавництво «Плеяди», 2006. 220 с.

21. Homiak I., Skrypnyk N. Training technologies as one of the forma of development of non-stardard communication in Ukrainian lessons. 
Norwegian Jornal of development of the Inernational Science. Oslo, Norway. 2019, № 37. C. 9-11.

22. Цвиллинг М.Я. Общественно-политический и научный текст как предмет обучения иностранным языкам. Москва : Наука, 1987. 200 с.

23. Handbook for teachers for exams from 2016. Cambridge English. URL: https://www.cambridgeenglish.org/Images/167791-cambridge-englishfirsthandbook.pdf (дата звернення: 18.04.2020).

\section{Information about the authors:} Skrypnyk N. I., Candidate of Philology Sciences, Head of the Ukrainian Philology Department Communal Higher Educational Institution "Vinnytsia Humanities Pedagogical College" 13, Nahirna str., Vinnytsia, 21000, Ukraine

Homiak I. M., Doctor of Pedagogical Science, Professor, Academician of the Academy of the Higher School of Ukrainian Language and Literature National University "Ostroh Academy" 2, Seminarska str., Ostroh, Rivne region, 35800, Ukraine 